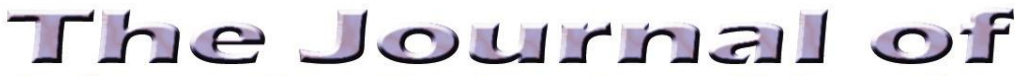 Information Technology Education
}

\section{Volume 7, 2008}

Editor-in-Chief: Linda Knight, DePaul University (USA)

Managing Editor: Eli B. Cohen, Informing Science Institute (USA)

Publisher: Elizabeth C. Boyd, Informing Science Institute (USA)

Cover Art: Michael Jones, University of Wollongong (Australia)

Associate Editors:

Chris Cope, La Trobe University (Australia)

Grandon Gill, University of South Florida (USA)

Dion Goh, Nanyang Technological University

(Singapore)

Mike Hart, University of Cape Town

(South Africa)

Beverley Hope, Victoria University of Wellington

(New Zealand)
Lynn Jeffrey, Massey University (New Zealand)

Paul Jerry, Athabasca University (Canada)

Zlatko Kovacic, The Open Polytechnic of New Zealand (New Zealand)

Jo Rhodes, University of South Australia (Australia)

Lorraine Staehr, La Trobe University (Australia)

Kam Vat, University of Macau (Macau)

Janice Whatley, University of Salford,(England)

The mission of the Journal of Information Technology Education is to:

- improve IT education around the world by publishing high quality articles on best practices and other topics of use in improving IT education,

- expose the reader to a variety of epistemologies and types of articles, including primary, action, and secondary research,

- provide those who submit manuscripts for publication with useful, timely feedback by making the review process constructive,

- be for the reader the most authoritative journal on IT education, and

- acknowledge and embrace the diversity of teaching and learning models in use around the world.

JITE is listed in Applied Math and Science Education Repository (AMSER), Cabell's Directory of Publishing Opportunities in Educational Curriculum \& Methods, Cabell's Directory of Publishing Opportunities in Educational Technology \& Library Science, Cabell's Directory of Publishing Opportunities in Management, Directory of Open Access Journals (DOAJ), EBSCO, ERIC, Index of Information System Journals, InSPEC, Intute, Ulrichs.

JITE is an academically peer reviewed journal. All submissions are blind refereed by three or more peers. JITE is published in print by subscription and its articles also appear online free of charge on the web site http://jite.org

ISSN: online 1539-3585; print 1547-9714; CD 1547-9706

Published by the Informing Science Institute 131 Brookhill Ct., Santa Rosa, California USA phone: +1-707-537-2211; fax: +1-480-247-5724 http://informingscience.org 


\section{Copyright of Material Published in the Journal of Information Technology Education}

Material published as part of this journal, either on-line or in print, is copyrighted by the Informing Science Institute. Permission to make digital or paper copy of part or all of these works for personal or classroom use is granted without fee provided that the copies are not made or distributed for profit or commercial advantage AND that copies 1) bear this notice in full and 2 ) give the full citation on the first page. It is permissible to abstract these works so long as credit is given. To copy in all other cases or to republish or to post on a server or to redistribute to lists requires specific permission and payment of a fee. Contact Publisher@InformingScience.org to request redistribution permission. 


\section{JITE Volume 7, 2008 - Table of Contents}

A Qualitative Investigation of an All-Female Group in a Software Engineering Course Project Anthony Cox and Maryanne Fisher

Ten Reasons for IT Educators to be Early Adopters of IT Innovations

Sharlett Gillard, Denice Bailey, and Ernest Nolan

Adding XML to the MIS Curriculum: Lessons from the Classroom

William P. Wagner, Vik Pant, and Ralph Hilken

Using a Problem-Based Learning Approach to Teach an Intelligent Systems Course

France Cheong

The Effectiveness of Screencasts and Cognitive Tools as Scaffolding for

Novice Object-Oriented Programmers

Mark J. W. Lee, Sunam Pradhan, and Barney Dalgarno

A Computer Science Educational Program for Establishing an Entry Point

into the Computing Community of Practice

Bruria Haberman and Cecile Yehezkel

Critical Skill Sets of Entry-Level IT Professionals: An Empirical Examination of

Perceptions from Field Personnel

Mark E. McMurtrey, James P. Downey, Steven M. Zeltmann,

and William H. Friedman

Towards the Development of a New Model for Best Practice and Knowledge Construction in Virtual Campuses

Antonio Cartelli, Mark Stansfield, Thomas Connolly, Athanassios Jimoyiannis, Hugo Magalhães, and Katherine Maillet

A Methodological Review of Computer Science Education Research

Justus Randolph, George Julnes, Erkki Sutinen, and Steve Lehman

Syndicated RSS Feeds for Course Information Distribution

Ronald J. Glotzbach, Dorina A. Mordkovich, and Jaime E. Radwan 163-183

Examining the Effects of Technology Attributes on Learning: A Contingency Perspective Jennifer Nicholson, Darren Nicholson, and Joseph S. Valacich

Changing Mental Models of the IT Professions: A Theoretical Framework

Denise E. Agosto, Susan Gasson, and Michael Atwood

Business Informatics: An Engineering Perspective on Information Systems

Markus Helfert

Factors that Influence Information Systems Undergraduates to Pursue IT Certification

D. Scott Hunsinger and Michael A. Smith 
Comparison of Face-To-Face and Hybrid Delivery of a Course that Requires

Technology Skills Development

Gary J. Senn

Framing Professional Development in Information and Communications Technologies:

University Perspectives

Johnnie Wycliffe Frank Muwanga-Zake

A Perspective on a Management Information Systems (MIS) Program Review

Bee K. Yew

An Introductory Course on Service-Oriented Computing for High Schools

W. T. Tsai, Yinong Chen, Calvin Cheng, Xin Sun, Gary Bitter, and Mary White

Twenty Years of Girls into Computing Days: Has It Been Worth the Effort?

Annemieke Craig, Catherine Lang, and Julie Fisher

\section{Innovations in Practice}

From Requirements to Code: Issues and Learning in IS Students'

Systems Development Projects

Elsje Scott IIP 1-13

Effectiveness of Program Visualization: A Case Study with the ViLLE Tool

Teemu Rajala, Mikko-Jussi Laakso, Erkki Kaila, and Tapio Salakoski

Survival Mode: The Stresses and Strains of Computing Curricula Review

Grace Tan and Anne Venable

The Pentagonal E-Portfolio Model for Selecting, Adopting, Building, and Implementing an E-Portfolio

Nicole Buzzetto-More and Ayodele Alade IIP 44-70

Enabling a Comprehensive Teaching Strategy: Video Lectures

H. David Brecht and Suzanne M. Ogilby IIP 71-86 